IJMS 17 (2), 183-199 (2010)

\title{
PEMBIAYAAN EKUITI MUSYARAKAH MUTANAQISAH (MMQ): PERUBAHAN DARIPADA AL-BAI' BITHAMAN AJIL (BBA) BERASASKAN PENGALAMAN TERAS DARA CONSORTIUM (TDC)
}

\author{
SANEP AHMAD \\ Fakulti Ekonomi dan Pengurusan \\ Universiti Kebangsaan Malaysia \\ NORA YUSMA MOHAMED YUSOP \\ Pengajian Pengurusan Perniagaan dan Perakaunan \\ Universiti Tenaga Nasional
}

\begin{abstract}
Abstrak
Sistem perbankan Islam adalah satu sistem yang menekankan keadilan berdasarkan konsep perkongsian keuntungan. Malangnya kebanyakan produk pembiayaan perbankan Islam masa kini adalah pembiayaan-hutang yang bercanggah dengan dasar keadilan perbankan Islam. Lantaran itu perbankan Islam perlu meningkatkan produk pembiayaan yang bercirikan keadilan berdasarkan pembiayaan-ekuiti. Sehubungan itu makalah ini cuba menerokai kemungkinan bagaimana pembiayaan-hutang boleh diubahsuai kepada pembiayaan-ekuiti. Pengubahsuaian akan dilakukan ke atas Bai Bithaman Ajil (BBA) memandangkan kaedah BBA merupakan kaedah yang paling banyak diamalkan pada masa kini. Analisis ubahsuai dilakukan secara teori daripada konsep murabahah dalam BBA kepada konsep musyarakah mutanaqisah $(M M Q)$, manakala bukti empirikal dilakukan berasaskan kepada pengalaman Teras Dara Consortium (TDC). Kajian mendapati bahawa konsep pembiayaan-hutang dalam BBA boleh diubahsuai kepada pembiayaan-ekuiti berkonsepkan MMQ. Pengalaman TDC membuktikan bahawa pengamalan konsep ini tetap mendatangkan keuntungan, dapat mempercepatkan unit jualan, dapat menambah penyertaan golongan berpendapatan rendah dan dapat mengubah motif pembiayaan daripada keuntungan kepada kebajikan. Implikasinya ialah perubahan sedemikian dapat meningkatkan fungsi sebenar perbankan Islam serta dapat meningkatkan taraf kebajikan masyarakat.
\end{abstract}

Kata kunci: Musyarakah Mutanaqisah (MMQ); Bai' Bithaman Ajil (BBA), pembiayaan asas hutang; pembiayaan asas ekuiti. 


\begin{abstract}
Introduction - Islamic banking system is a system which emphasises equity based on profit loss sharing. Unfortunately, current banking practice offers mostly product based on debt financing which resembles the conventional banking system. Thus Islamic banking should introduce more products based on equity financing. A possible method can be applied is by tranferring debt-based financing into equity-based financing.

Purpose - This paper examines the possibility of transforming debt-based financing of al-Bay' Bithaman Ajil (BBA) into equity-based financing Musyarakah Mutanaqisah (MMQ) with special reference to the experience of Teras DARA Consortium (TDC) and further explores its impact on social welfare.
\end{abstract}

Methodology - The study is theoretical in nature without emperical modelling analysis. Analysis will first be done theoritically based on the concept of leasing from $B B A$ into $M M Q$. Transformation should be done on $B B A$ due to the reason that $B B A$ is the most popular product offered by Islamic institutions in Malaysia. The experience of Teras Dara Consortium (TDC) will be reffered to examine the feasibility of this excercise.

Findings - Theoretically, BBA financing can be extended or modified into $M M Q$ financing. Furthermore, TDC's experiences showed that MMQ equity based financing can be successfully implemented and contribute to faster sales performances, increases the number of lower income participants, maintain profit gains, and enhance banking role in increasing social welfare benefits.

Originality/Value - The paper explores and shows the possible actions taken by the Islamic institutions for promoting equity and the real spirit of Islamic banking. It further addresses the implications of these actions to the financial institutions vis-a-vis the society.

Keywords - Musyarakah Mutanaqisah (MMQ); Bay' Bithaman Ajil; debtbased financing; equity-based financing; social welfare.

Paper type - Research paper.

\title{
Pengenalan
}

Perlaksanaan sistem kewangan Islam di Malaysia telah mengalami beberapa perubahan sejak mula diperkenalkan. Fasa satu bermula pada tahun 1983 merupakan fasa permulaan atau pengenalan

184 IJMS 17 (2), 183-199 (2010) 
kepada sistem perbankan Islam. Ini diikuti dengan fasa kedua yang memperkenalkan skim perbankan tanpa faedah bermula pada sekitar tahun 1993. Menjelang tahun 2000, skim ini kini dikenali sebagai skim perbankan Islam. Pada masa ini, usaha giat dilakukan untuk cuba melebarkan jaringan dan meningkatkan aset perbankan Islam dengan menggunaan kemudahan dan infrastruktur perbankan sedia ada seperti membenarkan bank konvensional membuka "Islamic window" bersama operasi sistem mereka. Kini kewangan Islam di anggap telah sampai kepada fasa ketiga, iaitu fasa untuk mengukuhkan perbankan Islam dengan sasaran syer pasaran $20 \%$ aset perbankan Islam berbanding perbankan konvensional menjelang 2010 (Mustafa, 2003). Bagi mencapai matlamat fasa ketiga ini, empat langkah kini dilakukan, iaitu membangunkan kapasiti institusi kewangan Islam yang kukuh, mengukuhkan rangka kerja kawal selia perundangan dan kawalan syariah, pembangunan rangkaian produk yang komprehensif dan berdaya saing, dan akhirnya memantapkan modal insan.

Dilihat dari sudut produk, pada masa kini perbankan Islam telah memperkenalkan lebih 50 produk. Produk tersebut dianggap setanding dengan produk bank konvensional serta dapat menjadi pengganti kepada produk mereka. Produk baru terus dicipta dan bertambah demi untuk memenuhi permintaan pengguna serta mencipta produk yang lebih menepati kehendak Syarak.

Walau bagaimanapun kebanyakan produk yang ditawarkan setakat ini khususnya dalam pembiayaan adalah berteraskan pembiayaanhutang yang tidak menekankan keadilan. Hanya sebahagian kecil sahaja produk yang menekankan keadilan berteraskan pembiayaan-ekuiti. Pembiayaan-hutang kerap dipersoalkan kebolehterimaannya kerana ianya mempunyai persamaan dengan konsep riba. Kebanyakan pengguna menganggap pembiayaanhutang yang diamalkan oleh perbankan Islam sebagai pembiayaan riba tetapi dalam bentuk yang lain. Demi untuk menzahirkan lagi kebaikan nilai Islam serta memenuhi tujuan sebenar perbankan Islam dalam menegakkan keadilan agihan dan kebajikan, maka amat wajar sekiranya perbankan Islam menambahkan lagi produk yang bermotifkan kebajikan berteraskan pembiayaan-ekuiti. Memandangkan tanggungjawab menegakkan keadilan dan membela golongan miskin dan berpendapatan rendah merupakan sebahagian daripada tuntutan Islam maka perbankan Islam seharusnya memberi perhatian kepada usaha ini. Lantaran itu amat wajar perbankan Islam meningkatkan lagi usaha untuk memperkenalkan lebih banyak produk yang bermotif kebajikan berteraskan konsep pembiayaanekuiti. 


\section{Kajian Lepas}

Perbankan Islam mempunyai beberapa pilihan dalam menawarkan produk pembiayaan iaitu sama ada pembiayaan berasaskan ekuiti atau pembiayaan berasaskan hutang. Pembiayaan berteraskan ekuiti yang dikenali sebagai pembiayaan-ekuiti adalah pembiayaan yang menggunakan konsep perkongsian risiko perniagaan seperti mudharabah (perkongsian keuntungan) dan musyarakah (usaha sama) (BIMB, 1994). Manakala pembiayaan berteraskan hutang pula adalah pembiayaan yang berkonsepkan tanggungan risiko seperti murabahah (kos tambah untung), Bai' Bithaman Ajil (pembiayaan berkala) dan ijarah thumma al-bai (sewa beli). Pembiayaan ini lebih dikenali sebagai pembiayaan-hutang (BIMB, 1994).

Namun demikian sebahagian besar pembiayaan yang dilakukan oleh perbankan Islam adalah berteraskan pembiayaan hutang. Sehingga tahun 2004 sistem perbankan Islam mengguna pakai 99\% produk berteraskan pembiayaan-hutang dan hanya $0.5 \%$ produk sahaja yang berteraskan pembiayaan-ekuiti-mudharabah dan musyarakah (BNM, 2003; 2004; 2005). Peratusan besar pembiayaan adalah berasaskan Bai' Bithaman Ajil. Jadual 1 menunjukkan bahawa peratusan terbesar pembiayaan hutang adalah bai bithaman ajil. Bagi penyata tahun 2003, peratusan pembiayaan menggunakan BBA adalah $47.7 \%$, diikuti oleh Ijarah (29\%) dan murabahah (6.2\%). Kontrak-kontrak lain dalam kategori ini merangkumi 16\%. Mudharabah dan musyarakah hanyalah terdiri daripada $0.5 \%$ sahaja.

Jadual 1

Pembiayaan Sistem Perbankan Islam

\begin{tabular}{llccr}
\hline \multirow{2}{*}{ Jenis Pembiayaan } & Jenis Produk & \multicolumn{3}{c}{ Peratusan } \\
\cline { 3 - 5 } & & 2003 & 2004 & 2005 \\
\hline \multirow{3}{*}{ Pembiayaan-hutang } & Bai bithaman Ajil & 47.7 & 49.9 & 40.7 \\
& Ijarah & 29 & 24 & 21.6 \\
& Murabahah & 6.2 & 7 & 6.9 \\
& Istisna' & 0.6 & 1.2 & 0.9 \\
& Kontrak lain & 16 & 17.4 & 19.6 \\
Pembiayaan- ekuiti & Mudharabah \& musyarakah & 0.5 & 0.5 & 0.3 \\
\hline
\end{tabular}

Sumber. BNM, 2003, 2004, 2005. 
Agihan pembiayaan bagi penyata tahun 2004, tidak banyak berubah. Peratusan pembiayaan menggunakan BBA adalah tertinggi dengan peratusan $49.9 \%$, diikuti oleh Ijarah $(24 \%)$ dan murabahah $(7 \%)$. Kontrak-kontrak lain dalam kategori ini merangkumi $17.4 \%$. Mudharabah dan musyarakah hanyalah terdiri daripada $0.5 \%$ sahaja. Bagi tahun 2005, pembiayaan ekuiti menurun kepada hanya $0.3 \%$ sahaja. Ini menunjukkan bahawa pembiayaan-ekuiti amat kurang diaplikasikan oleh perbankan Islam.

Bank yang mengamalkan sistem perbankan Islam seperti Bank Muamalat, Bank Islam Malaysia dan Maybank secara persendirian juga banyak menawarkan pembiayaan yang berteraskan pembiayaan-hutang. Keadaan ini dilaporkan oleh beberapa bank yang mengamalkan sistem perbankan Islam seperti Bank Muamalat (2005), Bank Islam Malaysia Bhd (2005) dan Maybank (2005). Keadaan ini tidak selari dengan motif sebenar penubuhan perbankan Islam. Penubuhan bank Islam mempunyai objektif penting, iaitu untuk menegakkan prinsip Islam dalam sistem perbankan dengan menawarkan produk alternatif yang menjamin keadilan agihan melalui konsep pembiayaan-ekuiti berteraskan perkongsian untungrugi mudharabah dan musyarakah. Ini adalah satu sistem yang seharusnya bebas sepenuhnya daripada unsur riba serta tidak boleh dihubungkait dengan riba (Ahmad, 1970), akan tetapi pelaksanaan masa kini menunjukkan bahawa ianya telah terpesong daripada objektifnya yang sebenar kerana pembiayaan-hutang masih boleh dihubungkaitkan dengan riba. Malah masyarakat menganggap pembiayaan-hutang yang diamalkan oleh perbankan Islam seperti BBA adalah menyamai pembiayaan perbankan konvensional dan dianggap sebagai riba dalam bentuk yang lain. Satu perkara yang lebih penting juga ialah kaedah BBA masih dipersoalkan kebolehterimaannya di sisi syariah. Kebanyakan fuqaha Timur Tengah menolak pelaksanaan BBA, malah ulama Pakistan yang dianggap menerima tetapi tidak mengalakkan ia dilaksanakan secara meluas (Council of Islamic Ideologi, Pakistan, 1977). Oleh itu, tibalah masanya agar kaedah ini dikurangkan pelaksanaannya atas dua alasan. Pertama mencari produk yang lebih Islamik dan bertepatan dengan syarak dan kedua mempertingkatkan lagi pembiayaan-ekuiti supaya terserlah objektif sebenar perbankan Islam.

Perbankan Islam dikatakan tidak menggemari pembiayaaanekuiti kerana walaupun mempunyai beberapa kelebihan kerana mengaplikasikan kontrak jual beli khususnya berkaitan dengan ganti rugi (Saiful Azhar Rosly, 2001) ianya juga mempunyai beberapa masalah. Selain daripada masalah pengawasan terdapat juga persoalan lain tentang pembahagian keuntungan. Namun 
demikian, Zakariya Man (1991) telah menyatakan sebenarnya mudharabah dan musyarakah mempunyai potensi yang baik untuk dikembangkan walaupun ianya mempunyai beberapa cabaran dalam melaksanakannya kerana sesetengah pengguna komited terhadap perbankan Islam berdasarkan asas keagamaan. (Jaafar Ahmad, Sanep Ahmad \& Zulkifli Ahmad, 1999). Masalah dalam perkongsian untung rugi yang dialami oleh perbankan Islam ialah bank sentiasa mendapat pulangan yang rendah sebagaimana dinyatakan oleh Maheran dan Shaharir (2005). Aplikasi pembiayaan ekuiti MMQ pula dijangka kurang menarik bagi pihak institusi kewangan (Ahmed Kameel Meera \& Dzuljastri, 2005).

Pembiayaan BBA dan MMQ mempunyai beberapa persamaan asas, iaitu pembelian secara tangguh tetapi ditambah dengan konsep berkongsi milikan dan sewa (Farid, Bilal Bin, et al., 2005). BBA adalah satu kaedah pembiayaan yang mana bank membeli harta yang dikehendaki oleh pelanggan secara tunai dan kemudian menjualkannya semula kepada pelanggan pada harga kos tambah untung dengan bayaran secara ansuran. Transaksi dalam produk BBA pada asasnya menggunakan konsep jual beli murabahah (tambah untung) pada kadar yang dipersetujui oleh kedua-dua pihak secara hutang. Pembayaran hutang tersebut dilakukan secara ansuran dalam jangka masa panjang yang dipersetujui oleh pihak yang terlibat. Secara umumnya kedua-dua pihak, iaitu individu dan institusi kewangan (Bank Islam) akan melaksanakan kontrak jual beli hutang ke atas harta yang dimaksudkan.

Kaedah musyarakah mutanaqisah pula adalah satu kontrak perkongsian yang berakhir dengan pemilikan sepenuhnya oleh satu pihak dan dengannya berakhirlah perkongsian (Mohammad Soffean Junaidi, 2003). Kontrak ini mengaplikasi dua jenis kontrak, iaitu pembelian secara milikan bersama dan sewa. Pelanggan dan institusi kewangan berkongsi bersama membeli harta yang kemudiannya disewakan kepada pelanggan. Harga sewa menjadi milik bersama pelanggan dan institusi kewangan mengikut jumlah syer yang dimiliki. Sewa yang dibayar oleh pelanggan akan diserahkan keseluruhannya kepada institusi kewangan dan dikira sebagai pembelian syer atas harta. Pengaplikasian konsep kongsi milikan yang akan dilakukan tolakan setiap kali bayaran dibuat akan menjadikan syer milikan harta berubah selepas setiap kali pembayaran dilakukan. Peratus milikan ke atas harta oleh institusi kewangan akan dikurangkan manakala peratus milikan ke atas harta oleh pelanggan akan bertambah sehingga akhirnya keseluruhan harta akan menjadi milik pelanggan. 
Perbandingan di antara dua kaedah tersebut menunjukkan bahawa kontrak BBA boleh diubah bentuknya kepada MMQ dengan melakukan tiga langkah berikut:

a) Pelanggan dikehendaki membayar pendahuluan dan jumlah bayaran ini dikira sebagai syer dalam milikan harta.

b) Harta yang dibeli disewakan kepada pelanggan. Nilai sewa menjadi milik bersama pelanggan dan institusi kewangan mengikut jumlah syer.

c) Bayaran sewa diserahkan keseluruhannya kepada institusi kewangan. Bahagian sewa milik pelangan yang diterima oleh institusi kewangan dianggap sebagai tambahan pembelian syer ke atas harta oleh pelanggan.

Melalui proses ini, pertama: pelanggan dan institusi pembiayaan bersama berkongsi harta yang dibeli mengikut kadar yang dibayar dan kedua: syer institusi kewangan akan menurun manakala syer pelanggan akan meningkat setiap kali bayaran sewa dilakukan oleh pelanggan dan ketiga: akhirnya keseluruhan harta akan menjadi milik pelanggan. Tidak dinafikan bahawa perlaksanaan pembiayaanekuiti mempunyai beberapa isu pro dan kontra, namun ianya tetap boleh diketengahkan. Bagi meningkatkan komitmen perbankan Islam yang mempelopori konsep pembahagian untung rugi, maka perlaksanaan konsep ini dalam produk pembiayaan perlu ditingkatkan. Pembiayaan-ekuiti sepatutnya dijadikan teras kepada pembiayaan dalam perbankan Islam. Persoalan penting sekarang ialah bagaimana pembiayaan-hutang boleh diubahsuai kepada pembiayaan-ekuiti, supaya perbankan Islam boleh menukar kaedah pembiayaan daripada pembiayaan-hutang kepada pembiayaanekuiti.

Memandangkan sebahagian besar pembiayaan-hutang yang diamalkan adalah berdasarkan konsep BBA, maka makalah ini akan cuba menganalisis tiga objektif berikut iaitu pertama, meneliti penggubahsuaian pembiayaan-hutang BBA kepada pembiayaanekuiti Musyarakah Mutanaqisah (MMQ) yang dilakukan oleh TDC; kedua, meneliti apakah kesan perubahan tersebut kepada pihak bank; dan ketiga, meneliti apakah kesan perubahan tersebut kepada kebajikan masyarakat.

Bahagian seterusnya akan membincangkan pengalaman TDC, pengubahsuaian konsep BBA kepada MMQ dan melihat kesan 
pelaksanaan tersebut kepada keuntungan syarikat dan juga kesan terhadap sosioekonomi masyarakat yang terlibat.

\section{Pengalaman Teras Dara Konsortium Sdn Bhd (TDC)}

\section{Latar Belakang TDK}

Teras Dara Konsortium Sdn. Bhd. adalah sebuah syarikat hartanah yang telah mengambil alih proses penjualan rumah daripada Lembaga Kemajuan Pahang Tenggara (DARA). Pada peringkat awal pengambilalihan terdapat lebih kurang 1,050 buah rumah yang terletak di 12 buah Bandar di dalam Wilayah Pahang Tenggara yang belum dijual kepada pihak awam. Rumah-rumah ini merangkumi rumah jenis mewah, kos sederhana dan kos rendah. Kawasan di mana syarikat mengalami kesukaran untuk menjual rumahnya secara prosedur biasa (pembiayaan melalui institusi kewangan) kepada penduduk ialah Kota Bahagia, Melati, Bandar Ibam, Kota Perdana, Paloh Hinai, Kota Shahbandar dan Perwira Jaya. Hal ini kerana kebanyakan penduduk yang mendiami kawasan tersebut terdiri daripada masyarakat yang sara hidup mereka bergantung kepada sektor pertanian dan perladangan. Bagi kawasan yang agak maju seperti di bandar Muadzam Shah penjualan rumah lebih berjaya dilakukan kerana taraf sosioekonomi penduduk di sini adalah lebih baik dan mereka lebih berkemampuan menggunakan pelbagai kemudahan pembiayaan daripada institusi kewangan.

Walau bagaimanapun bagi tujuan kajian ini, dua buah kawasan kajian telah dipilih, iaitu Kota Bahagia dan Melati. Pemilihan dua bandar ini adalah kerana proses penjualan rumah di bandar tersebut telah selesai dilakukan. Bermula dari Jun 1999 sehingga Mac 2000, pihak syarikat telah cuba untuk menjual rumah-rumah yang diambil alih daripada Lembaga Kemajuan Pahang Tenggara (DARA) melalui proses penswastaannya dengan menggunakan pendekatan biasa, iaitu penjualan dengan menggunakan kemudahan pembiayaan daripada bank atau institusi kewangan dan juga secara tunai.

Penjualan secara kaedah biasa yang diamalkan oleh pemaju perumahan kurang mendapat sambutan daripada penduduk tempatan kerana-faktor-faktor berikut: ${ }^{1}$

i. Penyewa semasa/bakal pembeli tidak mempunyai pendapatan tetap yang dapat meyakinkan pihak institusi kewangan untuk memberi kemudahan pinjaman bagi membeli rumah. 
ii. Penduduk masih berharap dengan kaedah penjualan secara sewa beli yang diamalkan oleh Kemajuan Pahang Tenggara (DARA).

iii. Pihak bank juga kurang berminat untuk membiayai pembelian rumah-rumah kayu yang terletak di pedalaman.

iv. Penduduk juga tidak mampu membayar kadar ansuran bulanan yang disediakan oleh pihak bank atau institusi kewangan.

v. Keadaan rumah yang rosak atau telah lama terbiar menyebabkan perbincangan yang berpanjangan di antara pembeli dengan pengurusan syarikat bagi mendapatkan harga yang boleh diterima atau tolak ansur daripada kedua-dua pihak.

Bagi meningkatkan penjualan rumah tersebut TDK telah menerangkan kaedah lain yang dijangka akan dapat menarik minat penyewa semasa untuk membeli rumah-rumah yang mereka duduki. Penjualan ini akan mengurangkan bebanan atau tanggungan syarikat ke atas rumah-rumah ini terutamanya kos penyelenggaraan, pembayaran insurans kebakaran, cukai tanah dan cukai pintu.

\section{Kaedah Jualan Teras Dara Konsortium Sdn. Bhd.}

Di dalam melaksanakan kaedah jualan yang dicadangkan tersebut, pendekatan yang digunakan oleh TDC adalah seperti berikut:

i. Harga jualan rumah adalah mengikut kadar harga yang ditetapkan oleh Jabatan Penilaian Negara, Kementerian Kewangan semasa menilai penswastaan aset DARA pada 13 Mei 1999.

ii. Kemudahan secara Bayaran Tertangguh ini hanya akan melibatkan semua rumah yang terletak di luar daripada Bandar Muadzam Shah. Bagi rumah-rumah yang terletak di dalam Bandar Muadzam Shah pembiayaan ini akan diguna pakai mengikut budi bicara syarikat sahaja. Kelayakan bagi pembeli rumah ini akan ditentukan oleh syarikat berdasarkan pendapatan bulanan/keupayaan membayar balik dan lain-lain faktor yang akan ditetapkan oleh syarikat.

iii. Semua sewa yang dibayar bagi tempoh mulai 1 Jun 1999 hingga sekarang akan dikira sebagai pendahuluan dan deposit dan akan ditolak daripada harga rumah. 
iv. Tempoh maksimum bagi menyelesaikan kesemua baki harga jualan ialah 15 tahun.

v. Bagi penyewa semasa, semua kerosakan yang wujud akan ditanggung oleh penyewa sendiri. Ini memandangkan semua kutipan sewa telah dikira sebagai bayaran pendahuluan dan ditolak daripada harga jualan.

vi. Bagi pembeli-pembeli baru (bukan penyewa semasa) semua kos kerosakan rumah akan diambil kira dan penilaian kerosakan akan dibuat oleh juru teknik syarikat. Maka kos kerosakan yang telah diluluskan akan ditolak daripada harga jualan rumah.

vii. Pembeli dikehendaki membayar wang pendahuluan sekurangkurangnya $10 \%$ daripada harga jualan. Walau bagaimanapun, jumlah bayaran yang lebih tinggi adalah digalakkan.

viii. Baki harga jualan rumah akan dikenakan caj perkhidmatan mengikut kaedah seperti:

a) Bagi mereka yang membayar wang pendahuluan melebihi 30\% daripada baki harga jualan, pembeli akan dikenakan caj sebanyak $5 \%$ setahun atas baki pokok yang belum dijelaskan.

b) Bagi yang membayar pendahuluan kurang daripada 30\% daripada baki harga jualan, maka caj yang dikenakan ialah 7\% setahun atas pokok yang belum dijelaskan.

c) Perkiraan $30 \%$ merangkumi pembayaran sewa yang lepas dan bayaran pendahuluan dibuat tetapi tidak mengambil kira kos kerosakan yang telah ditolak daripada harga jualan.

ix. Setiap pembeli yang bersetuju dengan konsep dan kaedah penjualan yang digunakan maka mereka dikehendaki menandatangani surat perjanjian yang disediakan oleh pihak syarikat dengan kos RM30.00.

x. Pembeli dikehendaki mengambil insurans gadai janji bagi melindungi kepentingan mereka terhadap premis ini. Semua urusan pembelian insurans gadai janji tersebut hendaklah diuruskan melalui syarikat tersebut dan premium yang terlibat akan dituntut daripada pihak pembeli. 
xi. Hak milik ke atas tanah dan rumah hanya akan diserahkan kepada pembeli setelah semua bayaran mengenainya dijelaskan secara sepenuhnya. Segala kos dan urusan pindah milik tersebut akan ditanggung oleh pihak pembeli.

Pada realitinya, apa yang ketara berbeza di sini adalah pihak Syarikat Teras Dara Konsortium Sdn. Bhd. telah menetapkan kadar CRRnya pada nilai $5 \%$ dan $7 \%$ dan tempoh pembiayaan maksimum ditetapkan pada 15 tahun atau 180 bulan bagi setiap pembiayaan yang diberikan oleh pihak TDC (Unit Jualan dan Kutipan, 2000). Penetapan kadar $5 \%$ atau $7 \%$ CRR ini sebenarnya adalah bergantung kepada faktor berikut:

i. Bagi pembeli yang membayar deposit pembelian rumah di bawah kadar 30\%, maka CRR yang di kenakan ke atas mereka ialah $7 \%$ manakala;

ii. Bagi pembeli yang membayar deposit pembelian rumah sekurang-kurangnya $30 \%$ dan ke atas, mereka layak untuk mendapatkan kadar CRR pada 5\%.

Selain itu, bagi pembeli yang bukan terdiri daripada penyewa, pihak syarikat akan mengambil kira kos kerosakan rumah memandangkan rumah yang dijual ini bukanlah rumah baru. Pihak syarikat telah melantik juruteknik penilaian kerosakan bagi menilai kos kerosakan yang terlibat dan kos ini akan ditolak daripada harga jualan tersebut.

Walau bagaimanapun, bagi pembeli yang tidak mampu untuk membaiki sendiri kerosakan tersebut, pihak syarikat akan membaiki sendiri kerosakan tersebut dan kos ini telah diambil kira dalam harga jualan tersebut. Secara tidak langsung tindakan ini akan dapat mewujudkan hubungan dua hala antara orang kaya dengan orang miskin dan antara golongan pembeli dengan pengusaha dalam mewujudkan satu bentuk kerjasama dan tolak ansur serta persefahaman dalam masyarakat. Sebagai rumusannya kos penolakan sebahagian daripada harga jualan ini boleh dipecahkan kepada dua kategori iaitu:

i. Bagi penyewa semasa, semua bayaran sewa akan diambil kira dari tarikh 1 Jun 1999 dan bayaran sewa ini akan di tolak daripada harga jualan.

ii. Bagi pembeli baru, mereka mempunyai dua alternatif iaitu:

a) meminta syarikat menolak kos kerosakan daripada harga jualan, atau 
b) meminta pihak syarikat membaiki kerosakan dan kos kerosakan tidak akan ditolak daripada harga jualan.

Jika diperhati dengan diteliti, pendekatan yang diambil ini amat bersesuaian dengan konsep Musyarakah Mutanaqisah kerana secara tidak langsung konsep penolakan sewa serta konsep bayaran tertangguh ini telah menepati instrumen Musyarakah Mutanaqisah (MMQ). Proses perubahan tersebut dianggap sebagai satu perubahan daripada kaedah BBA kerana bayaran pendahuluan sama ada kurang atau lebih daripada $30 \%$ adalah dianggap sebagai kadar perkongsian permulaan milik pelanggan terhadap harta yang dibeli.

Pengiraan Harga Jualan, Keuntungan dan Pembayaran Balik mengikut skim tersebut bagi kes bayaran pendahuluan kurang daripada $30 \%$ iaitu, $10 \%$ dan $30 \%$ dengan andaian harga aset ialah RM25,000 boleh ditunjukkan dalam Jadual 2 di bawah (Unit Jualan dan Kutipan TDC, 2000).

Jadual 2

Pembiayaan TDC

\begin{tabular}{lll}
\hline & Kes 10\% & Kes 30\% \\
\hline Harga rumah & RM25,000.00 & RM25,000.00 \\
Bayaran pendahuluan & $30 \%($ RM7,500.00) & $10 \%($ RM2,500.00) \\
Kos pembiayaan & RM17,500.00 & RM22,500.00 \\
Tempoh bayaran & 20 tahun & 20 tahun \\
Kaedah bayaran & Bulanan & Bulanan \\
CRR & $5 \%$ & $7 \%$ \\
Bayaran bulanan & RM115.4844 & RM174.436 \\
Jumlah bayaran balik & RM27,716.2777 & RM41,864.8463 \\
Jumlah keuntungan & RM10,216.2777 & RM19,364.8463 \\
Jumlah bayaran sebenar & RM35,216.2777 & RM44,304.8463 \\
\hline
\end{tabular}

\section{Impak Pelaksanaan Skim TDC}

Secara umumnya, kemudahan pembiayaan yang diberikan oleh syarikat pemaju ini telah memberikan dua implikasi, iaitu pertama

194 IJMS 17 (2), 183-199 (2010) 
ke atas prestasi syarikat TDK dan kedua ke atas pembangunan sosioekonomi masyarakat setempat.

\section{Kesan ke atas Pembangunan Sosioekonomi Masyarakat}

\section{Memenuhi keperluan golongan berpendapatan rendah}

Daripada 230 buah rumah yang dijual, 197 unit rumah dijual dengan menggunakan kaedah bayaran tertangguh. Ini bermakna pihak syarikat tersebut telah berjaya membantu segelintir masyarakat yang tidak berkemampuan untuk membeli rumah dengan menyediakan kemudahan pembiayaan seperti ini. Ini terbukti daripada kajian soal selidik yang dilakukan di mana 95\% daripada responden mengatakan rumah merupakan perkara terpenting yang diperlukan oleh mereka pada ketika ini. Walaupun secara umumnya rumah kediaman yang dijual ini bukanlah merupakan satu perumahan baru tetapi ia memberi makna yang besar kepada penduduk setempat yang rata-rata masih tidak mempunyai kediaman sendiri. Kenyataan ini disokong oleh pendapat yang dikemukakan oleh responden di mana $90 \%$ responden mengatakan sangat bersetuju manakala $10 \%$ lagi mengatakan bersetuju bahawa rumah yang dibeli ini merupakan harta yang bernilai kepada mereka.

\section{Memenuhi tanggungjawab sosial dengan menjaga kebajikan masyarakat}

Daripada kajian soal selidik yang dilakukan didapati kesemua responden mengatakan amat bersetuju bahawa penyediaan keperluan rumah yang mencukupi dan berkualiti dapat memenuhi tanggungjawab sosial pihak swasta tersebut dan secara tidak langsung dapat meningkatkan taraf kebajikan sosial mereka. Ini kerana pencapaian kebajikan ekonomi untuk ahli masyarakat adalah matlamat penting dalam ajaran Islam.

\section{Memelihara hubungan antara pihak korporat dengan masyarakat}

Dengan terlaksananya keadilan sosial dalam masyarakat tersebut, maka secara tidak langsung ianya akan dapat mewujudkan suasana persaudaraan dan kerjasama di antara organisasi korporat atau swasta dengan anggota masyarakat terbabit. Bank dan pelanggan bersama berkongsi membeli harta yang akhirnya akan menjadi milik pelanggan. 


\section{Peningkatan taraf hidup masyarakat}

Memenuhi keperluan daruriyyah masyarakat seperti menyediakan keperluan perumahan, memberi kemudahan pembiayaan serta memenuhi keperluan kemudahan asas di kawasan ini secara tidak langsung dapat meningkatkan taraf penduduk kampung asal yang telah lama tinggal dan juga penduduk yang baru datang berhijrah di situ. Secara amnya kemudahan pembiayaan yang disediakan oleh syarikat ini telah mewujudkan satu rantaian ekonomi yang amat menarik ke atas penduduk setempat yang mana ianya telah memberi sumbangan yang positif kepada pembangunan sosioekonomi masyarakat.

\section{Impak ke atas Prestasi TDC Sdn. Bhd.}

\section{Peningkatan jualan}

Jumlah jualan bagi tahun 2000 adalah RM1,466,000.00. Daripada jumlah tersebut, RM647,000.00 atau $44.13 \%$ adalah jualan dengan kaedah pembiayaan BBA oleh syarikat manakala bakinya $55.87 \%$ atau RM819,000.00 adalah pembayaran oleh institusi kewangan, bank dan tunai. Jumlah jualan telah meningkat pada tahun 2001 selepas TDK melaksanakan konsep BBA yang berbeza. Jualan dengan kaedah pembiayaan BBA menjadi $50.69 \%$ meliputi nilai jualan RM3,360,370.00. Bakinya sebanyak RM3,269,075.70 atau $49.31 \%$ adalah jualan melalui kaedah pinjaman bank atau institusi kewangan.

Daripada jumlah jualan RM6,629,445.70 tersebut, jumlah unit rumah yang dijual adalah 230 unit dengan nilainya RM4,419,170.00 dan bakinya adalah bagi jualan premis perniagaan dan lot industri. Ini menunjukkan bahawa unit jualan premis rumah kediaman, ruang niaga dan lot industri telah meningkat.

\section{Kesimpulan}

Pelaksanaan kemudahan pembiayaan yang disediakan oleh Teras Dara Konsortium ini bukan sahaja telah berjaya membantu syarikat mencapai sasaran jualan malah secara tidak langsung ianya telah memberi peluang kepada masyarakat kurang berkemampuan di luar bandar untuk memiliki rumah kediaman sendiri. Berdasarkan kepada perlaksanaan kaedah pembiayaan oleh TDC, terdapat beberapa manafaat yang dapat dirasai secara langsung dan tidak langsung oleh syarikat mahupun masyarakat di sekitarnya iaitu: 
1. Dapat meningkatkan jualan syarikat melalui bayaran tertangguh memandangkan kaedah penjualan sebelum ini didapati kurang berkesan.

2. Dapat membantu menyelesaikan masalah kesukaran mendapatkan kemudahan pembiayaan oleh pembeli yang tidak berkemampuan.

3. Dapat mewujudkan satu hubungan mesra antara pihak korporat dengan masyarakat setempat.

4. Dapat meningkatkan taraf penduduk masyarakat luar bandar dengan menyediakan keperluan perumahan untuk mereka.

5. Dapat meringankan beban pembeli di mana bayaran bulanan adalah lebih rendah .

6. Bagi pembeli yang mempunyai pendapatan yang agak terhad, kemudahan bayaran tertangguh ini bukan sahaja tidak membebankan mereka malah mereka dapat mengatur dan merancang belanjawan mereka dengan lebih baik dan teratur.

7. Kemudahan bayaran tertangguh ini memberi peluang kepada masyarakat luar bandar yang kurang kemampuan untuk memiliki rumah kediaman yang mereka idamkan dan secara tidak langsung telah dapat memelihara keperluan daruriyyah dalam masyarakat serta dapat meningkatkan taraf kebajikan masyarakat luar bandar.

Umum mengetahui bahawa kemudahan pembiayaan oleh institusi perbankan hanya diberikan kepada mereka yang memenuhi syarat yang ditetapkan oleh pihak bank. Pemberian kemudahan pembiayaan oleh syarikat ini membuktikan kepada kita bahawa tanggungjawab sosial bukan hanya merupakan tanggungjawab yang harus dipikul oleh pihak kerajaan semata-mata, malah keterlibatan dan komitmen yang diberikan oleh pihak swasta ini telah membuka mata banyak pihak terutamanya pihak pemaju perumahan dan pihak institusi kewangan agar menganggap masalah masyarakat merupakan masalah yang perlu ditangani bersama.

Walau bagaimanapun, tidak dinafikan juga bahawa kaedah bayaran tertangguh ini turut mendatangkan masalah aliran wang tunai kepada syarikat terbabit memandangkan penjualan dilakukan secara hutang dan memakan masa yang panjang untuk dilangsaikan.

IJMS 17 (2), 183-199 (2010) 


\section{Nota Akhir}

1. Temu bual dilakukan dengan Pengurus Unit Jualan dan Kutipan, Haji Ab.Ghani bin Mustafa, pada 3 Mac 2002, pada pukul 3.30 petang di Pejabat Unit Jualan Kutipan Muadzam Shah Pahang Darul Makmur.

\section{Rujukan}

Ahmad, Sh. Mahmud. (1970). Banking in Islam. Paper presented at the International Conference on Islamic Economics, Islamabad: Islamic Research Institute.

Ahmed Kameel Mydin Meera, \& Dzuljastri Abdul Razak. (2005). Islamic home financing through Musharakah Mutanaqisah and al-Bay' Bithaman Ajil contracts: A comparative analysis. Paper presented at the International Conference on A Universal Paradigm of Socio-Scienstific Reasoning. 17-18 December 2005, BIAM Auditorium, Dhaka.

Bank Islam Malaysia Bhd. (2005). Laporan Tahunan 2005.

Bank Negara Malaysia. (2003). Laporan Tahunan 2003.

Bank Negara Malaysia. (2004). Laporan Tahunan 2004.

Bank Negara Malaysia. (2005). Laporan Tahunan 2005.

BIMB. (1994). Islamic banking practice: From the practicioner's perspective (pp. 50). Kuala Lumpur: Bank Islam Malaysia Bhd.

Council of Islamic Ideology, Government of Pakistan. (1977).

Farid, Bilal Bin, Chong Kok Loong, Khairul Fahmi Mahmud, Khairul Hidir Ghazali, Said Anuar Said Ahmad \& Syed Hilal Syed Ghazali. (2005, March). Essence of Musharakah Mutanaqisah partnership Vs Bai' Bithaman Ajil. A Project Paper Presented for the Course Money, Banking and Capital Markets, International Islamic University Malaysia.

Jaafar Ahmad, Sanep Ahmad \& Zulkifli Ahmad. (1999). Analisis gelagat pelanggan terhadap SPTF (Laporan Penyelidikan). Fakulti Ekonomi \& Perniagaan dan BIRST.

Laporan Tahunan BNM, (2003, 2004, 2005)

Laporan Tahunan Bank Muamalat. (2005).

Laporan Tahunan Bank Islam Malaysia Bhd. (2005).

Laporan Tahunan Maybank. (2005).

Maheran Mohd Jaffar \& Shaharir Mohammad Zain. (2005). Kelemahan amalan Bank Islam dalam pembahagian untung pelaburan Mudharabah, dalam Prosiding Seminar Matematik dan masyarakat (hlm. 136-144). KUSTEM, Terengganu.

Maybank. (2005). Laporan Tahunan 2005. 
Mohammad Sofean Junaidi. (2003). Musharakah Mutanaqisah (Diminishing Musharakah): A floating rate option for Islamic banking in Brunei Darussalam. (Unpublished master's thesis). International Islamic University, Malaysia.

Mustafa. (2003). Belanjawan 2004: Ke arah menjana aset perbankan Islam di Malaysia (pp. 36-37). Dewan Ekonomi, Disember.

Saiful Azhar Rosly. (2001). Iwad as a requirement of lawful sale: A critical analysis. IIUM Journal of Economics and Management, 9(2), 187-201.

Surtahman Kastin \& Sanep Ahmad. (2005). Ekonomi Islam: Dasar dan amalan (2nd ed.). Kuala Lumpur: Dewan Bahasa dan Pustaka.

Teras Dara Konsortium Sdn. Bhd. (2000). Cadangan menjual rumah menggunakan kaedah sewabeli/bayaran tertangguh. Kertas Kerja oleh Unit Jualan dan Kutipan, TDC, Muadzam Shah, 1.

Unit Jualan Dan Kutipan Teras Dara Konsortium Sdn.Bhd (2000). Kertas Cadangan.

Zakariya Man. (1991). Islamic banking: Prospect for Mudharabah and Musharakah Financing. Dalam Abu Hassan M Sadeq, Development \& Finance in Islam (pp. 55-69). Petaling Jaya: International Islamic University Press. 